\title{
Främlingar, fiender och medborgare
}

\author{
Bidrag till en analys av främlingsfientlighet i Sverige
}

\section{JOSE ALBERTO DIAZ}

Huvudtesen $i$ artikeln är att analysen av främlingsfientlighet bör fokuseras på två typer av faktorer som sammanfaller med detta fenomens dubbla förankring $i$ den sociala verkligheten. Dels bör främlingsfientligheten relateras till frägan om hur enskilda människor upplever invandrare och invandring i bestämda sociala sammanhang. Dels innebär fenomenet även en kollektiv dimension.

Frågan som många ställer sig i dessa dagar av växande etnisk intolerans är varför svenskarnas överlag liberala hållning och vänlighet mot invandrare och främlingar har förändrats på bara några år till en betydligt kyligare och även mer fientlig inställning. Någon kanske påpekar att negativa attityder alltid har funnits i bakgrunden, att det som händer i dag egentligen inte är något nytt. Kanske det. Men även om detta vore sant återstår fortfarande att förklara varför främlingsfientligheten har blivit så mycket mera utbredd och grövre

Jose Alberto Diaz är fil.dr. i sociologi och verksam vid Sociologiska institutionen vid Uppsala universitet. Hans avhandling handlade om invandrarnas integration i Sverige. För närvarande forskar han om främlingsfientlighet. idag än tidigare. Enligt flera färska opinionsmätningar ogillar inte mindre än 60 procent av svenskarna den nuvarande flyktingpolitiken. Hur många av dessa svenskar som inte heller gillar de människor som berörs av denna politik vet vi inte, men de lär inte vara mycket färre än de s.k. flyktingmotståndarna. Ty vi vet från tidigare forskning att de finns ett starkt samband mellan negativa attityder till invandrare och kritiska åsikter mot flyktingpolitik (Lange och Westin 1984).

Enligt en undersökning om ungdomarnas inställning till invandring är dagens ungdomar mera negativt inställda till invandrare och flyktingar än i tidigare mätningar (Lange och Westin 1991). I jämförelsen med tidigare undersökningar om 
vuxna svenskar skiljer sig ungdomar mycket markant från den övriga befolkningen. I samma rapport instämmer helt eller med tvekan inte mindre än 40 procent av ungdomar i åldern 16-21 i påståendet "Ju mindre man märker av alla utlänningar i Sverige desto bättre är det«. Många fler (63 procent) ger samma svar när de tar ställning till påståendet "Många utlänningar kommer till Sverige bara för att utnyttja våra sociala förmåneru. Vidare instämmer nästan hälften (46 procent) helt eller delvis i att »Vi bör inte släppa in några fler invandrare i Sverigeu.

Här handlar det om enstaka frågor i opinionsundersökningar som i bästa fall ger fragmentariska bilder av en komplex verklighet. Men borde inte dessa mätningar ändå säga oss något viktigt om opinionsläget? Det är ju inte bara frågan om oerhört starka främlingsfientliga ställningstaganden. Det handlar också om dagens svenska ungdomar, en generation av svenskar som är uppväxt i ett något mer heterogent samhälle än den äldre generationen. Det är en generation som har lärt sig främmande språk och rest mycket utomlands - båda faktorerna har enligt tidigare forskning ett klart samband med en positivare inställning till invandrare. Men det finns tydligen andra mera negativa faktorer som påverkar ungdomarna i en annan riktning. De aktuella forskningsuppgifterna borde ge dem som hade hoppas på radikala attitydförändringar redan hos dagens unga generation, en ordentlig tankeställare.

En del bidrag till diskussionen av dessa frågor har ägnats åt att definiera främlingsfientlighet och därmed fastställa hu- vuddragen i detta fenomen. Kommissionen mot rasism och främlingsfientlighet ${ }^{1}$ och opinionsledande medier betonar att främlingsfientligheten innebär negativa känslor mot främlingar och att detta fenomen är mindre allvarligt än rasistiska yttringar. Andra analyser betonar den organiserade främlingsfientligheten och dess politiska instrumentalisering $\mathrm{i}$ händerna på högerextremistiska krafter (t.ex. Lööw 1993, Lodenius och Larsson 1991). Men analysen av främlingsfientlighet kommer sällan längre än till allmänna eller taktiska-politiska övervägande. Det som däremot behövs är klarläggande av innehåll, uttrycksformer och betydelse för människors sociala och praktiska liv.

\section{Två dimensioner}

Min utgångspunkt i denna uppsats är att den kollektiva företeelse som kallas främlingsfientlighet är en komplex och mångfacetterad sådan. Den teoretiska och (tentativt) metodologiska frågeställningen som min diskussion nedan fokuserar på är följande: Hur kan vi definiera och analysera främlingsfientlighetens olika sidor? Vilka är företeelsens olika ansikten? Hur hänger de ihop? Hur kan man motverka dem?

Min huvudtes i denna artikel är att analysen av främlingsfientlighet bör fokuseras på två typer av faktorer som sammanfaller med detta fenomens dubbla förankring i den sociala verkligheten. Dels bör främlingsfientligheten relateras till

1. Se de etablerade definitionerna av främlingsfientlighet och rasism som föreslagits i den parlamentariska utredningen, SOU 1989: 13. 
frågan om hur enskilda människor upplever invandrare och invandring $i$ bestämda sociala sammanhang, snarare än att hänvisa till kulturella, psykologiska eller taktisk-politiska faktorer vilket är brukligt i den svenska debatten. Dels innebär fenomenet främlingsfientlighet även en kollektiv dimension genom vilken konkreta sociala antagonismer (dvs. fientlig-, motståndareförhållanden) kopplas till känslor av identitet och solidaritet med en större mänsklig gemenskap bland de infödda, nämligen nationen.

Det är existensen av ett nationellt "vi" som gör det möjligt för den främlingsfientlige att kollektivt definiera främlingar som ett antagonistiskt "dem" $i$ vilket alla de som inte anses höra hemma $i$ den svenska nationella gemenskapen ingår. Det som i början är i huvudsak individrelaterade konflikter och spänningar (inskränkta kanske till grannskaps- och arbetsplatsmiljöer) kan under vissa omständigheter utvecklas till att bli en antagonism mellan två större kollektiv som oförsonligt ställs mot varandra. $\AA$ ena sidan, har vi den svenska nationella gemenskapen till vilken enbart alla de infödda hör - vilket definieras på basis av nationellt ursprung och etnicitet (kulturell bakgrund, religion, wrasu) - och å den andra, främlingarnas gemenskap i vilken alla de andra avvikande ingår. Men främlingsfientlighet är inte bara frågan om ett kollektivt ställningstagande mot en något abstrakt kategori av främlingar. I denna analys vill jag särskilja en dimension av personlig antagonism i relation till invandrare, som är en andra väsentlig komponent av fenomenet främlingsfientlighet.
Det handlar alltså om en företeelse som fångar en kombination av både konkreta individrelaterade antagonismer och antagonismer som definieras i relation till nationen. Med andra ord: det finns en mikrosociologisk och nästan "privat" antagonismaspekt av främlingsfientlighet vid sidan om en ideologiserad och makropolitisk dimension i vilken sociala normer och kollektiv identitet ställs emot varandra på ett antagonistiskt sätt.

I den första typen av antagonismer har vi också en kollektiv dimension men den definieras på »lägre» sociala nivåer. Antagonismer skapas $i$ - och kan i vissa fall även begränsas till - mindre sociala enheter av människors relationer, där individer eller smågrupper agerar i relation till andra. Ett antagonistiskt förhållande till bestämda främlingar kan således utformas i de små gemenskapen, på arbetsplatser, i bostadsområden. Skälen till att vissa kategorier av infödda individer utvecklar denna attityd är i regel av social och ekonomisk karaktär, vilket Charles Westins forskning om attityder till invandrarna ger många bevis för.

\section{Illegitim konkurrens}

De inföddas fientlighet riktad mot enskilda etniskt avvikande individer på gruppnivån eller i närmiljön, är i många fall beroende av svenskarnas upplevelser av någon form av konkurrens från invandrarnas sida. Det kan vara frågan om konkurrens om olika typer av bidrag, bostäder, jobb, dagisplatser och även kvinnor. Sådan konkurrens, som är en naturlig företeelse ett västerländsk samhället, och 
som den främlingsfientlige får stå ut med när det gäller andra infödda svenskar, upplevs som illegitim och oacceptabel när det är fråga om invandrare. Anledning till detta är just uppfattningen att de inte är riktiga svenskar, dvs. att de inte tillhör den svenska nationella gemenskapen. Dessutom kan vissa beteendemönster eller individer uppfattas som ett visst (potentiellt) hot mot den personliga säkerheten, tryggheten, egendomen, etc.

När det gäller den andra gemenskapsdimensionen av främlingsfientlighet har vi en fientlighet riktad mot en större kategori av avvikande individer (även mot de som inte är involverade i lokala eller personliga antagonismer) därför att de tillägnas en viss etnisk eller nationell tillhörighet som avviker från majoritetsbefolkningen. Denna kombination avspeglar sig väl i den främlingsfientliges utsagor om enskilda invandrare eller förhållanden som alltid söker legitimering med hänvisning till ett större vi, den nationella gemenskapen.

I en ganska trivial typ av insändare kan denna uppfattning formulera sig t.ex. så här i relation till flyktingarna: „Vad kostar de egentligen? Det får $v i(=$ alla infödda svenskar) aldrig reda påı². För den främlingsfientlige fungerar ofta hänvisningen till en större (nationell) vi-gemenskap som ett slags täckmantel som både legitimerar och bekräftar ett ställningstagande mot

\footnotetext{
${ }^{2}$ Insändaren (Dagens nyheter den 12 oktober 1980) återges och analyseras i "Invandrarna ger mig angest". Om invandrarfientlighet, opinionsyttringar och behovet av syndabockar Géza Nagy och Bertil Nelhans (red), Invandrarförlaget, Borås 1984.
}

invandrare som förmodligen har sin grund i personliga eller situationsbetingade reaktioner gentemot främlingar. Med kopplingen till nationen skapar den främlingsfientlige intrycket att hans/hennes motiv inte bara gäller större och allvarligare ting än vardagliga individrelaterade konflikter och antagonismer, utan också att de delas av många andra.

Kort sammanfattat är min tes att främlingsfientlighet som en social företeelse bör förklaras i termer av personliga antagonismer mot enskilda invandrare orsakade i huvudsak av sociala faktorer som överflyttas till att bli en kollektiv antagonism i vilken den nationella gemenskapen ställs mot alla främlingar, invandrare och flyktingar. Det finns givetvis också i enskilda fall andra typer av faktorer som påverkar främlingsfientligheten, t.ex. psykologiska (frustration, dålig självtillit) men de är av mindre intresse för en analys av generella tendenser. Som exempel på sociala faktorer kan i detta sammanhang nämnas de inföddas upplevelser av konkurrensförhållanden och upplevelser av relativ deprivation i relation till vissa kategorier av främlingar ${ }^{3}$. Relativ deprivation innebär i detta sammanhang att vissa infödda upplever att de i ett eller flera avseenden har det sämre än andra individer/

\footnotetext{
${ }^{3}$ Hypotesen att majoritetens upplevelser av relativ deprivation och minoriternas konkurrens leder till negativ särhandling av de avvikande har diskuterats i litteraturen bl.a. av Vanneman och Pettigrew (1972). En empirisk analys av orsaksförhållanden mellan relativ deprivation och norrmännens inställning till invandrare/asylsökande finns i Hernes och Knudsen (1989), Jenssen och Pedersen (1991).
} 
grupper som de jämför sig med. Upplevelser av relativ deprivation skapar negativa reaktioner som kan vända sig mot bestämda utgrupper eller samhällsinstitutioner (Hernes och Knudsen 1989:30). Det finns alltså infödda som skyller den relativa förlusten på invandrarna. Hernes och Knudsen (1989) har t.ex. redovisat empiriskt belägg för hypotesen att de som upplever relativ deprivation vill i större grad än andra kompensera sig i termer av fördomar mot andra grupper. Enligt Jenssen och Pedersen (1991) är de inföddas konfliktmedvetenhet (som beror på relativ deprivation och låg utbildning) en central variabel för att förklara attityder till invandrare.

Men saknas den andra gemenskapsdimensionen handlar det inte om den typ av samhällsrelevant främlingsfientlighet som vi definierar det här, nämligen en nationaldefinierad främlingsfientlighet som oförsonligt ställer infödda svenskar mot alla invandrade medborgare. Det som är frågan i detta fall är antagonismer av mera lokal eller (inter)personell karaktär i vilken den etniska faktorn är närvarande, men inte offensivt projiceras på frågan om den nationella identiteten. Fientligheten är inte i detta fall etniskt neutral, men den är inte heller helt $i$ grunden beroende av etnicitet. Det kan bli fråga t.ex. om en normal personlig fientlighet mellan individer som av olika skäl har misslyckats med att skapa vänskapliga relationer sinsemellan. Fientligheten blir således ett "privat" ställningstagande. Den saknar en större social dimension och är därmed samhällspolitiskt irrelevant. På det sättet kan antagonismens effekter begränsas till den privata eller den lokala sfären. För att använda en populär metafor från den svenska idépolitiska debatten: mellanetnisk fientlighet begränsas i detta fall till "den lilla världen".

I den motsatta situationen, dvs. när en personlig upplevelse och erfarenhet av antagonistisk karaktär saknas, föreligger förmodligen ovilja eller misstro mot invandrare, men inte nödvändigtvis främlingsfientlighet - allt detta under förutsättning att det inte finns rasistiska eller nyrasistiska motiv som följer en helt annan logik men har en stark och selektiv främlingsfientlig effekt. Det är just i kombination av dessa två typer av antagonismer, i både den lilla och den stora världen, där vi finner det unika och det hotande med det sociologiska fenomenet vi kallar främlingsfientlighet.

Hur omfattande är dessa mellanetniska antagonismer i dagens Sverige? Vilka systematiska forskningsinsatser har man gjort på det området? Det mest intressanta bidraget är här onekligen Charles Westins och Oskar Langes forskning vid Centrum för invandringsforskning i Stockholm. De har gjort riksrepresentativa och kontinuerliga uppföljningsstudier av svenskarnas attityder till invandring och invandrare. Deras forskningsresultat har därmed en systematisk grund som saknas i de tillfälliga opinionsmätningar som rapporteras i medierna.

För att tentativt kunna uppskatta den empiriska dimensionen som denna typ av antagonismer kan komma att utveckla i dagens Sverige, blir vissa datauppgifter från Langes och Westins publicerade undersökningar mycket suggestiva. I tabel- 
lerna 1-2 redovisas svarsfrekvenser för ett flertal frågor som på basis av den ovan presenterade hypotesen vi antar kan relateras till de två typer av antagonismer som utgör grunden för främlingsfientligheten.
Medan Tabell 1 presenterar svenska attityder som kan kopplas till en "nationell preferens" när det gäller fördelningen av samhällsresurserna, visar Tabell 2 attytidsvängningar som skildrar de inföddas upp-

\section{Tabell 1}

Svenskarnas inställning till invandring/invandrare. Andel $i \%$ som instämmer helt och instämmer delvis på följande påståenden.

Det gäller framför allt att se till att landets egen befolkning har arbete!

\begin{tabular}{|c|c|c|c|}
\hline \multirow[b]{2}{*}{1969} & \multicolumn{3}{|c|}{ Undersökningsår } \\
\hline & 1981 & 1987 & $1990(*)$ \\
\hline 90 & 80 & 80 & 81 \\
\hline 80 & 66 & 67 & 61 \\
\hline 45 & 32 & 29 & 40 \\
\hline
\end{tabular}

Det är inte mer än rättvist att svenskarna, som har byggt landet, i första hand fär dra nytta av vår höga produktion!

Ju mindre man märker av alla utlänningar i Sverige, desto bättre är det!

(*) Gäller enbart svenska ungdomar |6-2| år gamla. Källa: Westin 1987, Lange och Westin 1991.

\section{Tabell 2}

Svenskarnas inställning till invandrare. Andel $i$ \% som instämmer helt och instämmer delvis på följande påståenden.

\begin{tabular}{lcccc} 
& \multicolumn{5}{c}{ Undersökningsår } \\
& 1969 & 1981 & 1987 & $1990\left(^{*}\right)$ \\
\cline { 2 - 6 } $\begin{array}{l}\text { Många utlänningar kommer till Sverige bara } \\
\text { för att utnyttja våra sociala förmåner! }\end{array}$ & 73 & 50 & 51 & 63 \\
$\begin{array}{l}\text { Vi har fått en ökad arbetslöshet i Sverige } \\
\text { därför att invandrarna har tagit svenskarnas } \\
\text { arbeten! }\end{array}$ & 43 & 30 & 28 & 29 \\
$\begin{array}{l}\text { Bostadsbristen är beroende till stor del } \\
\text { av invandringen! }\end{array}$ & 35 & 18 & 26 & 60 \\
$\begin{array}{l}\text { Vi bör inte släppa in fler invandrare till Sverige! } \\
\text { Många invandrarkillar kommer hit och snor }\end{array}$ & 45 & 44 & 33 & 46 \\
svenska tjejer! \\
$\begin{array}{l}\text { (*) Gäller enbart svenska ungdomar 16-2I år gamla. } \\
\text { Källa Westin 1987, Lange och Westin 1991. }\end{array}$
\end{tabular}


fattningar om hur de upplever konkurrensen från invandrade medborgare. Två tentativa slutsatser kan dras från dessa datauppgifter. $\AA$ ena sida visar uppgifterna från Tabell 1 att andelen av majoritetssamhället som kan tänkas kunna ställa sig bakom den främlingsfientliga parollen "Svenskarna först?" är ganska omfattande. En rimlig tolkning av den första frågan är att en överväldigande majoritet klart anser att de infödda svenskarnas intresse bör prioriteras när det gäller konkurrensen om arbetstillfällen.

$\AA$ andra sida visar frekvenserna i Tabell 2 att konkurrensförhållanden om andra typer av samhällsresurser upplevs negativt av mer än en fjärdedel av majoritetsbefolkningen. Så många upplever t.ex. 1981 och 1989 att infödda svenskarnas bristande tillgång till bostäder och jobb beror på invandrarna. En klar majoritet har också en negativ upplevelse av invandrarnas konkurrens om bidrag och andra välfärdsresurser.

\section{Främlingsfientlighet: en eufemism för rasism?}

Med termen främlingsfientlighet finns en risk att den används alltför ofta när man $\mathrm{i}$ stället borde tala om rasism. En anledning till det är svenskarnas väldokumenterade ovilja att prata om rasism vilket beror på denna terms starka och negativa laddning. Håller främlingsfientlighet på att bli en eufemism för rasism? Det tror socialantropologen Christer Lindberg (1991) som hävdar att termen rasism har blivit "ersatt av uttrycket främlingsfientlighet». Vidare beklagar han sig över att han fort- farande »inte mött någon som lyckats förklara vad som avgränsar begreppet främlingsfientlighet från etnocentrism respektive rasism". Lindberg är inte ensam om det. Om denna iakttagelse är riktig bör vi ägna större analytiskt intresse åt frågan om hur man avgränsar begreppet främlingsfientlighet från rasism, och även från etnocentrism.

Det vårdslösa bruket att termen främlingsfientlighet som eufemism för rasism måste starkt ifrågasättas. Det bidrar till att bagatellisera rasismens betydelse i det svenska samhället. Det är därför viktigt att man definierar tydliga och verklighetsrelaterade kriterier för en klar avgränsning mellan företeelserna. Frågan om vad främlingsfientlighet och rasism har gemensamt måste också diskuteras. Främlingsfientlighet till skillnad från traditionell rasism (som grundas på en uppfattning om biologiska skillnader och rashierarkier) är ett fenomen som definieras i en bestämd relation till den nationella gemenskapen. Främlingsfientligheten kan således $i$ nagon mening vara rasneutral. Vidare är främlingsfientlighet också generellt sett ett fenomen av sociologisk karaktär och därför är den också i grunden till skillnad från rasismen - av icke ideologisk karaktär. Med andra ord, samhällsrelevanta former av främlingsfientlighet har i regel en sociologisk förklaring vid sidan av symboliska och även psykologiska motivstrukturer.

Men främlingsfientlighetens relation till ett avvisande som grundas i rasmässiga stereotyper kan inte anses vara annat är tvetydig. Mer eller mindre förstuckna rasistiska uppfattningar kan finnas i många 
fall bakom en främlingsfientlig inställning. Men rasuppfattningar kan inte anses vara ett tillräckligt villkor för att främlingsfientlighet - som vi förstår den i denna analys - ska kunna manifesteras. Främlingsfientlighet kan taktiskt användas för att dölja ett rasistiskt budskap, vilket är fallet i dagens Sverige med vissa nya nyrasistiska grupperingar som framträder med en polerad fasad och nyanserat ideologiskt budskap. I vissa fall har deras företrädare akademisk träning och har lärt sig att uppträda intellektuellt när de förmedlar sitt budskap om patriotism och kulturella skillnader. Men rasmässiga stereotyper kan även saknas i vissa främlingsfientliga attityder. Det är fallet när de drabbade har ett nordiskt ursprung.

Särskilt svårt att reda ut tycks vara förhållandet mellan främlingsfientlighet och nya former av rasism som kan identifieras i Europa och Sverige de senaste åren ${ }^{4}$. I dessa former av post-biologisk rasism framställs ett konsekvent avvisande av vissa kategorier av främlingar som beroende av kulturella skillnader vilket i regel sammanfaller med bestämda etniska och rasmässiga stereotyper (Diaz 1992). Dessa egenskaper anses definiera en bestämd nationell tillhörighet och identitet, vilket uppfattas som oförenlig med de inföddas kulturarv och nationella traditioner.

Vid verkliga förhållanden är kriterierna

${ }^{4}$ Det finns flera europeiska bidrag till denna analys: Etienne Balibar 1991 och framför allt PierreAndré Taguieff (1985) som har formulerat den mest sofistikerade analysen av nyrasism i Frankrike. Det första svenska bidraget till dess analys finns i Diaz 1992; se även Banakar 1993. för att fastställa relationen mellan de tre nämnda nationella, rasmässiga och kulturella faktorerna inte alltid entydiga. Icketillhörighet i den nationella gemenskapen kan avgöras i relation till ett påtagligt annorlunda nationellt ursprung, t.ex. det faktum att man inte är född i värdlandet vilket inte är detsamma som en juridisk medborgarestatus. Men den kan också definieras i förhållanden till fenotypiska drag (hudfärg, utseende) eller kulturella aspekter som religion, språk, beteendemönster. Alla tre centrala aspekter (nation, ras och kultur) kan blandas i lite olika kombinationer. I vissa fall kan de överlappa varandra så att t.ex. nationellt ursprung sammanfaller med bestämda kulturella egenskaper eller också med vissa fenotypiska drag. Men i regel finns inte ett enda bestämt urskiljbart kombinationsmönster.

\section{Nation, ras eller kultur?}

Ett centralt antagande i min diskussion av främlingsfientlighet är att detta fenomens grundläggande logik inte bygger på en hierarkisk uppfattning om "raser" (som traditionell rasism), kulturer (vilket är vad etnocentrismen indirekt eller direkt definierar) eller en ambivalent blandning av både i vilken den kulturella skillnaden har en dominerande roll. Det senare är en grundföreställning i de nyrasistiska ideologier som legitimerar en diskriminerande och avvisande särbehandling av invandrare i namn av den kulturella mångfalden och majoritetens rätt till att bevara differensen i relation till de "andra". Främlingsfientlighetens grundläggande och speci- 
fika logik är att den bygger på något annat, nämligen på ett särskilt förhållningssätt till nationen.

Främlingsfientligheten ifrågasätter alltså inte i första hand de främmandes "ras" eller kultur utan det faktum att de inte tillhör nationen. Där ligger grunden för en definition av de andra som främlingar, dvs människor från "främmande länder" som inte anses tillhöra den mest betydelsefulla och omfattande vi-gemenskapen bland de infödda, den nationella gemenskapen. Här kan man fråga sig vad som är det väsentliga i definitionen av denna nationella gemenskap? För att kunna svara på denna fråga behöver vi en uppfattning om nationen i relation till vilken en föreställning om nationell identitet historiskt utformas. Det är inte denna artikels syfte att recensera den omfattande litteratur som ägnats àt begreppet "nation "s. Inte heller avses här att tillföra detta begrepp något nytt. En viktig utgångspunkt för vår diskussion är den engelske filosofen Ernest Gellners välkända verk Nation and Nationalism. Han framhåller att nationen vanligtvis definieras av forskarna i relation till två centrala aspekter: en gemensam kultur (dvs ett system av idéer, symboler, kommunikations- och beteendemönster) och människors vilja att erkänna varandra som tillhörande samma nation. Beroende på var

\footnotetext{
${ }^{5}$ För en kritisk analys av både s.k. "subjektiva" och "objektiva» definitioner av nation se Erik Hobsbawms Nations and Nationalisms, Cambrigde University Press 1990. Relevant i litteraturen är också Benedict Andersons definition av nation som "an imagined community" $i$ en bestämd territoriell kontext (se B. Anderson, Imagined Communities, London: Verso 1983).
}

man lägger betoningen talar man om en kulturell eller voluntaristisk uppfattning om den nationella gemenskapen (Gellner 1983). I samband med dessa två dimensioner kan vi nu definiera främlingskap i mellanetniska sammanhang.

Att vara främling innebär alltså en distinktion som de infödda markerar i båda ovannämnda avseenden, dvs. en främling är en person som saknar "rättı kulturell bakgrund och som - i stor sett av samma skäl - inte är accepterad som en likvärdig medlem $\mathrm{i}$ de inföddas gemenskap. Båda faktorerna förklarar följaktligen att en viss kategori av människor lämnas utanför den nationella gemenskapen. Här ligger, enligt min mening, en av grundförutsättningarna för främlingsfientlighet. Men resonemanget måste preciseras för att undvika missuppfattningar. De inföddas förhållningssätt mot främlingar kan givetvis variera och endast under vissa förhållanden intar den nationella differensen de aggressiva och extremt intoleranta former som kännetecknar främlingsfientlighet.

Det ovillkorliga exkluderandet av de avvikande från den nationella gemenskapen som ligger bakom den välkända främlingsfientliga principen »en gång invandrare, alltid invandrare« manifesteras i all sin outhärdlighet i fallet med andragenerationens invandrare. För de som passivt eller aktivt ställer upp på den främlingsfientliga gränsdragningen mot de avvikande har det knappast någon betydelse hur länge de som en gång invandrat till Sverige med sina föräldrar har bott i landet. Inte heller spelar det någon roll hur mycket de har lyckats med sin personliga integration och anpassning i Sverige. 
De flesta förstagenerations invandrare har lärt sig att känna igen och framför allt att beakta majoritetens oskrivna gränsdragning när det gäller nationell identitet och tillhörighet. De som inte gör det, kommer förr eller senare med olika grader av råhet att bli undervisad om saken av de som vaktar den nationella gemenskapens integritet. Och de är flera än vad man tror. Barn som är uppvuxna eller födda i Sverige men kanske har "fel " förälder klassas i regel av svenska institutioner och enskilda som invandrarbarn, dvs. någon som i grunden är precis som sina föräldrar, en främling. Det handlar sällan om individer som inte kan de grundläggande språkliga och kulturella koder som gäller i det nya landet. Men ändå erkänns de i regel inte av de infödda som en av "dem".

I den mån det skulle finnas något som kan kallas den andra eller den tredje generationens återvändande till sina etniska rötter - vilket har tematiserats av Marcus Lee Hansen's välkända teori i USA $^{6}$ - borde detta tolkas mindre i termer av ett genuint val mellan två tillgängliga alternativ. Det kan lika väl vara en indirekt effekt av utstötningen som följer majoritetens restriktiva gränsdragningar mot främlingar. Många av dem som inte släpps in väljer, skulle jag tro, alternativet att göra dygd av nödvändighet och söka en

\footnotetext{
${ }^{6}$ Hansens klassiska teori som fått varierande stöd vid senare forskningsprövningar formulerades 1937 i essän "The Problem of the Third Generation Immigrant». I Kivisto och Blank (1990) finns det flera uppsatser som ägnas åt att diskutera den teoretiska giltigheten och den historiska/sociologiska relevansen i Hansen's "law of the third generation return".
}

identitet och gemenskap i den egna minoritetens kultur och band till föräldrarnas ursprungssamhälle.

Den etniska gränsdragningen mellan majoritet och minoritet lämnar således vissa kategorier av människor utanför den nationella gemenskapen. Dessa människor är och förblir i något fundamentalt avseende främlingar. Men att man är främling måste inte nödvändigtvis innebära att man är fiende. Det senare inträffar endast under vissa speciella omständigheter. En del s.k. strukturella faktorer kan skapa viktiga förutsättningar för att detta ska kunna inträffa, t.ex. sociala eller politiska konflikter i mångkulturella nationalstater, internationella eller regionala kriser, ekonomisk nedgång. Den auktoritära statsmodellen som i det moderna Europa lanserades av den "konservativa revolutionen" innebär ett historiskt exempel på hur politiken skapar strukturella förutsättningar för uppfattningen om en samhällsgemenskap som bygger på intern (etnokulturell) homogenitet och utestängning av pluralism och heterogenitet (Jaschke 1992).

Men strukturella faktorer räcker ej för att förklara uppkomsten av en socialt utbredd främlingsfientlighet. Det behövs också att människor har en mer direkt upplevelse av en nationell identitet och erfarenhet av antagonismer mot andra människor för att de ska kunna engagera sig i aggressiva handlingar mot externa fiender. Ty främlingsfientligheten kännetecknas av ett påtagligt engagemang och en viss aggressivitet som i regel saknas vid andra typer av besläktade företeelser som t.ex. främlingsrädsla eller - misstro. 


\section{Nation och främlingsfientlighet}

Enligt den tes som diskuteras här finns det två centrala mekanismer som påverkar den subjektiva upplevelsen av invandringen i främlingsfientlig riktning. Den ena har att göra med spänningar och konflikter som skapas i antagonistiska förhållanden mellan infödda och främlingar i mindre sociala sammanhang. Den andra har att göra med den sociala konstruktion (inkluderande ideologiska och även legalpolitiska aspekter) av nationell identitet och nationalkänsla som påverkar människors upplevelser av tillhörighet (identitet) med den nationella gemenskapen. Här finns det tyvärr ingen möjlighet att gå in på hur dessa två mekanismer utformas, verkar och interagerar i viktiga sfärer av samhällslivet. Men en ytterligare resonemang om relationen mellan nation och främlingsfientlighet kan föras.

Den ovan definierade makrosociologiska mekanismen i fenomenet främlingsfientlighet kan närmare belysas med ett resonemang vi lånar från Gellners (1983) diskussion om nationen. Historiskt sett manifesterar sig en nation i något väsentligt avseende genom känslomässiga yttringar ("sentiments»). Det är denna dimension av känslor som ger oss en viktig nyckel för att förstå människors reaktioner när de upplever att något väsentligt som tillhör den nationella gemenskapen kränks av andra, av främlingar, dvs. människor som bor $i$ andra länder (oftast grannländer) och just därför inte ingår $\mathrm{i}$ denna gemenskap.

Dessa främmande människor kan un- der vissa speciella omständigheter omvandlas från att vara harmlösa främlingar till potentiella eller verkliga fiender och som behandlas därefter. En del militära aktioner eller olika typer av politiska handlingar från berörda stater kan tolkas som ett hot mot de s.k. nationella intressena. Detta drabbar ofta relationerna mellan människor från de olika berörda länderna. I andra fall kan det som "de andra" gör eller säger uppfattas som en kränkning av de nationella traditionerna, symbolerna eller kulturarvet. Men undantag av dagens konflikter i det forna Jugoslavien är denna typ av nationell främlingsfientlighet som bygger på territoriella förhållanden ganska ovanlig i dagens Europa. Mitt i skapandet av det europeiska samarbetet och transnationella institutioner riktas numera inte främlingsfientliga känslor mot territoriella grannar i närområdet.

Men de infödda i Europa kan utveckla föreställningar om att det föreligger en viss risk för kränkningar eller övergrepp i samband med etniska minoriteter eller en relativt omfattande invandrarpopulation, dvs från främlingar som en gång utvandrat från sina ursprungsländer för att permanent bosätta sig i det land som i praktiken blir ett andra hemland för dem och deras barn. En viktig faktor som bestämmer den känslomässiga reaktionen inför hotbilderna är beroende av bl.a. tidigare erfarenhet av migrationsrörelser som haft negativa konsekvenser för samhället. Det kan också bero på existensen av levande nationalistiska traditioner som lätt kan manipuleras av organiserade grupperingar med bestämda invandrarpolitiska syften. Ingendera av dessa två faktorer tycks vara 
relevanta i Sveriges fall. Det är därför rimligt att anta att i Sverige är hotföreställningar i samband med invandringen mera beroende av direkta och interpersonella upplevelser än av starka nationella (och nationalistiska) traditioner som fallet är i andra länder.

Hypotesen om en nationellt grundad antagonism tycks också hjälpa oss att förstå varför efterkrigstidens Sverige haft en utveckling som i stort sett är fri från hårdare mellanetniska motsättningar och främlingsfientlighet. Det lär finnas flera förklaringar till varför den s.k. svenska modellen under en lång tid gav intrycket av att den hade klarat av både en generös flyktingmottagning och en kontroll av främlingsfientligheten. Det är inte utan betydelse att invandringen till Sverige under en lång tid har varit av relativt begränsad omfattning. En annan förklaring är landets ekonomiska tillväxt på 50- och 60talen som möjliggjorde en smidig integrering av arbetskraftsinvandrare på arbetsmarknaden. Tillväxtperioden skapade ett ekonomiskt välstånd som möjliggjorde en generös och jämlik fördelning av samhällsresurser mellan invandrare och svenskar en fördelning som inte ifrågasattes av de senare.

Men minst lika viktig som andra faktorer är det faktum att svenskarna varken har haft en stark nationell identitet/känsla eller någon relevant nationalistisk tradition i landets moderna historia. Författaren P.C. Jersild ${ }^{7}$ frågat provokativt vad Sverige egentligen är: „Finns det en svensk identitet och en modern historiebeskriv-

${ }^{7}$ P.C. Jersilds artikel i Dagens nyheter den 14/6/92. ning som de flesta är eniga om?». Hans svar är nej. Det som finns är, menar han, olika bilder av en svensk nationell identitet beroende på skilda (och relativt aktuella) partipolitiska reaktioner inför internationalisering och landets anpassning till EG.

Om denna iakttagelse är korrekt, saknar svenskarna en bild av sig själva ur ett historiskt perspektiv. Och utan historia finns det varken en stark nationell känsla eller nationalism. Ty som den engelske samhällsteoretikern Eric Hobsbawm (1992) påminde oss nyligen: "What make a nation is the past", vilket för övrigt förklarar yrkeshistorikernas betydelse för den sociala konstruktionen av nationer och nationalismer. Hobsbawm, själv ledande historiker i England, sammanfattar denna ofta ganska tvivelaktiga yrkesprestation med en smula ironisk mening: „We supply the essential raw material for the market". Huruvida det var fel på efterfrågan eller de intellektuellas utbudet $i$ den sociala konstruktionen av nationell identitet och känsla för Sverige kan inte bedömas här. Men för min diskussion av främlingsfientlighet ser jag mycket goda empiriska och teoretiska skäl för att formulera en arbetshypotes angående fränvaron av både en stark nationalism och en nationell identitet som en viktig förklaring till att Sverige hit tills har skonats frän bredare och gröure former av främlingsfientlighet.

\section{Nationalidentitet och medborgarskap}

Till skillnad från andra ansatser till främlingsfientlighet som betonar psykologiska, 
massmediala faktorer eller partipolitisk taktik är kärnan i min diskussion här att denna företeelse måste analyseras i relation till nationella preferenser och konkreta antagonismer i mindre sociala sammanhang. De senare antas utformas framför allt i hårdnande mellanetniska konkurrensförhållanden och dess medföljande upplevelser av ofördelaktiga konsekvenser hos resurssvaga infödda. Sedan bör frågan om kopplingen till den nationella gemenskapen och identiteten undersökas. Av denna ansats framgår att $i$ analysen av främlingsfientlighet är det oundvikligt att man kommer in på tre huvudteman som varken har diskuterats eller studerats tillräckligt i detta sammanhang: konkurrensförhållanden, nationalism och medborgarskap.

Det första är en klassisk sociologisk frågeställning som av utrymmesskäl inte har kunnats diskuteras mer ingående i denna artikel. Här behövs bättre teori- och forskningsinsatser med syfte att klarlägga tendenser och problem i konkurrensförhållanden mellan svenskar och invandrare i olika samhällssfärer, där kampen om knappa (och delvis minskande) resurser är hårdast. Viktigt är alltså att definiera strukturen i dessa sfärer, typer av resurser, konfliktintensitet samt de specifika kategorier av inblandade individer. Inom samhällsvetenskaplig migrationsforskning är det framför allt Langes och Westins (1984, 1987 och 1991) ovannämnda undersökningar som är de viktigaste källorna för en kvantitativ utvärdering och förståelse av antagonistiska mellanetniska relationer t.ex. i termer av de inföddas hotföreställningar om invandringen och in- vandrarnas konkurrens. En begränsning i detta forskningsarbete är att det saknas en konsistent begreppsmässig och analytisk ansats som kopplar samman konkurrensförhållanden och främlingsfientlighet.

När det gäller nationalism har det sagts ovan att den till skillnad från främlingsfientlighet är en ideologisk och politisk företeelse. Nationalism kan i grunden anses vara en specifik form av etnocentrism som utvecklas till ett politiskt projekt. Vi har ovan kort diskuterat främlingsfientlighet i relation till nationell identitet men inte kunnat gå in på temat nationalism. Men om den i denna artikel postulerade hypotesen om främlingsfientlighetens dubbeldimension är riktig drar vi slutsatsen att man borde ägna diskussion och större forskningsinsatser åt frågan om relationen mellan främlingsfientlighet, å ena sida, och nationell identitet och nationalism, å den andra. En central fråga som kan ställas här är huruvida förespråkare av det mångkulturella samhället kan göra detta projekt förenligt med ett aktiv bejakande av en nationell identitet. Till de som ger denna fråga ett positivt svar måste nästa fråga lyda: hur går detta ihop?

Mer konkret handlar det här om huruvida svenskarnas genuina och sunda bejakande av sitt eget nationellt ursprung och sin egen nationalidentitet går att koppla samman med ett mångetniskt samhällsliv utan främlingsfientlighet och rasism. Denna aspekt av mellanetniska relationer har en brännande politisk innebörd redan idag och kommer förmodligen att bli mycket viktigt i framtiden, framför allt i samband med EG/EU och en för Sverige nyfödd nationalkänsla som håller på att 
växa fram hos vissa kategorier av infödda medborgare.

Själv tror jag inte att det finns ett enkelt svar på frågan om en kombination av etnisk mångfald med ett genuint (och $\mathrm{i}$ visst avseende nödvändigt ur ett majoritetsperspektiv) bejakande av nationell känsla kan existera utan att spela i händerna på de främlingsfientliga krafterna. Bättre insikt och kunskap tycks alltså behövas för att förstå kopplingen mellan dels den nationella identiteten och nationalismen, dels främlingsfientlighet och -rädsla. Tyvärr har nationalism blivit ett fenomen som inte uppmärksammats varken i sociologiska studier i allmänhet eller i aktuella analyser av främlingsfientlighet i synnerhet.

När det gäller medborgarskap är det viktigt att omvärdera dess möjligheter att bli ett viktigt invandrarpolitiskt instrument för att öka samhörighet och tillhörighet $\mathrm{i}$ en nationell gemenskap, som inte bygger på exkluderande etniska eller kulturella principer. Medborgarskap är ett central komponent i invandrarnas politiska integration (Diaz 1993:166-7). En vid definition av politisk integration innebär att invandrarna har tillgång till både fullständiga politiska rättigheter (via naturalisering), och till fullt utövande av sociala och politiska medborgarroller (Diaz 1993b). Frågan om hur effektivt detta instrument kan bli för att påverka integrering av dem som saknar blodsband eller etnisk tillhörighet i det nya landet, kommer att bero på hur majoritetssamhället definierar det förvärvade medborgarskapet ur både ideologisk och social-praktisk synpunkt. Denna fråga kan mer konkret diskuteras med hjälp av Zygmunt Baumans (1990) analys av nationalstatens roll i det post-moderna samhället.

Ett centralt antagande i vår diskussion här är att de demokratiska institutionerna med hjälp av medborgarskapslagstiftningen kan positivt påverka en definition av bestämda solidaritets- och vänskapsrelationer inom ramen för en nationell gemenskap som inte bygger på rasmässiga eller etniska gränsdragningar (Diaz 1993). Enligt Zygmunt Baumans tes har nationalstaten en central roll för att påverka de sociala processerna av integration eller exkluderande av främlingar i en samhällsgemenskap. Nationalstaten kan legitimera och förstärka bestämda "collectivizations of enemies and friends" (Baumans 1990:152), som utformas på de små, nära gemenskapernas nivå ("the tribusu). Tack vore nationalstaten kan dessa fiendebilder göra sig gällande för alla kategorier av främlingar (även för de som inte är involverade $\mathrm{i}$ de ursprungliga fiendeantagonismerna) som inte anses ingå i samhällsgemenskapen.

När det gäller mellanetniska relationer kan en positiv effekt av nationalstaten antas verka på minst två sätt. Dels genom att neutralisera antagonistiska förhållanden som utformas på lägre samhällsnivåer, främst på grund av det som ovan karakteriserades som upplevelser av illegitim konkurrens. Viktigt är här att staten hindrar att främlingsfientligheten von unten utvecklar sig till en faktor som påverkar de nationella institutionerna. Dels kan den moderna statsbildningen aktivera de identifikationspotentialer som gynnar invandrarnas inlemmande i ett samhälls- 
gemenskap som inte byggs på etniska principer (såsom religion, språk, nationellt ursprung).

Två av de stora samhällsförändringarna i det post-moderna samhället ser Bauman i statens skiljande från nationen (som definieras av etniska principer), och i statens likgiltighet inför kulturella och etniska skillnader (1990:167-8). Det är i denna samhällsutveckling som en pragmatisk integrationsorienterad medborgarskapsnorm inte bara kan upphäva $i$ något väsentligt avseende verkan av "the collectivization of enemiesu som gestaltas i lokala antagonismer. Minst lika viktigt är att ändamålsenliga medborgarskapsnormer leder till att majoritetssamhället accepterar de främlingar som aldrig blir riktiga "fiender", utan tvärtom utvecklar vänskapsförhållanden i det nya landet. Medborgarskap kan öppna för dem dörren till fullvärdigt medlemskap i den nationella gemenskapen.

Kanske är den ideologiska konstruktionen av en modern mångkulturell nation ännu i våra dagar beroende av hur det organiserade samhället väljer mellan den franska eller den tyska medborgarskapsmodellen ${ }^{8}$. Den första grundar nationen, nationell tillhörighet i universalistiska värderingar (mänskliga rättigheter) och folkets politiska vilja. I denna modell kan en form av politisk patriotism skapas i vilken lojalitet till de demokratiska institutionerna och normerna är det fundamentala kriteriet för att dra skiljelinjerna mellan vänner och fiender. Här har invandrare som är beredda att acceptera majoritetssamhällets krav på politisk (re)socialisering och integration (som bör ta sig uttryck i beslutet att förvärva svenskt medborgarskap) en rimlig möjlighet att ingå som fullvärdigt medlem $i$ den svenska samhällsgemenskapen. Och tvärtom: väljer man en tysk modell som grundar nationen och nationell identitet $i$ etnisk homogenitet och blodsband, blir det omöjligt att ge invandrade medborgarna och sina barn en plats i den nationella gemenskapen. De är och förblir främlingar. Och främlingar utgör alltid ett potentiellt hot $\mathrm{i}$ ett samhälle som grundar sin social organisation i någorlunda förutsägbara "vänfiender relationer (Simmel).

De potentialer som finns i medborgarskapet för inlemmandet av personer med invandrarbakgrund som har utvecklat en viss känsla av identitet med det nya landet - vilket oundvikligt sammanfaller, enligt etablerad sociologisk kunskap, med graden av integration och ackulturering - bör inte överdrivas, men har, enligt min mening, inte riktigt utnyttjats av de demokratiska krafterna i Sverige. David Schwarz (1992) har nyligen korrekt betonat vikten att ompröva den gällande synen på medborgarskapsfrågan och behovet att göra den till ett viktigt element $i$ en ny integrationsorienterad invandrarpolitik. Han har också en del förslag som enligt min mening utgör en viktig utgångspunkt för en mera konkret diskussion av policyförändringar i den inriktning.

${ }^{8}$ För en aktuell invandringsrelaterade diskussion av dessa två modeller se W. R. Brubaker 1990.

Diaz - Främlingar, fiender och medborgare 


\section{Slutkommentar}

Som socialt fenomen har främlingsfientlighet definierats i denna artikel som en kombination av två typer av antagonismer: en som bestäms av en - i huvudsak - etnisk tillhörighet i den nationala gemenskapen och en annan som bygger på konfliktförhållanden på grupp- och individnivån. $V i$ vet för lite idag, enligt min mening, om de konkreta mekanismerna genom vilka dessa två typer av antagonistiska förhållanden relateras till varandra. Min hypotes här har varit att den kollektiva fientlighet som bygger på en uppfattning om nationell tillhörighet och identitet är en projicerad antagonism som tjänar som legitimering av en personlig fientlighet den senare antas i regel kunna ges en sociologisk förklaring.

Vi har också skisserat några tankegångar - utifrån det analytiska perspektivet som presenterats ovan - angående vissa problemområden vilka vi borde öka vår förståelse och kunskap för. Utan denna kunskap om grundläggande sociala mekanismer som ligger bakom människors attityder är det svårt att tänka sig handlingsstrategier som med framgång skulle kunna bekämpa främlingsfientligheten i Sverige.

Avslutningsvis vill jag betona en allmän slutsats i denna diskussion när det gäller huvudinriktningen på samhällets möjligheter att bekämpa främlingsfientlighet. Från min diskussion ovan drar jag slutsatsen att den viktigaste handlingslinje man måste följa är att hindra den explosiva sammankopplingen av individuella eller lokala antagonismer med nationalistiska ställningstagande. Lyckas man med den uppgiften kommer främlingsfientligheten med stor sannolikhet att bli politiskt impotent. Därmed förlorar en viktig barriär mot invandrarnas integrering all samhällsrelevans i egenskap av kollektiv företeelse. Avgörande för kampen mot främlingsfientlighet blir således våra ansträngningar att hålla isär och bemöta med olika åtgärder dels en social dimension av spänningar, kulturell olikhet, verklighetsförankrad rädsla ${ }^{9}$ och även personlig fientlighet - som oundvikligt uppstår när människor konkurrerar om olika typer av begränsade och i dagens läge krympande resurser - och dels den sociala konstruktionen av en nationell identitet och känsla som alltid riskerar att oförsonligt ställa mot varandra den svenska nationella gemenskapen mot alla avvikande främlingar. I Frankrike har man som bekant inte lyckas särskilt väl med denna uppgift. Det återstår att se om Sverige klarar sig bättre.

\footnotetext{
${ }^{9}$ Viktigt är i detta sammanhang att »skilja mellan en rädsla som föds i människornas praktiska liv och är i någon objektiv mening verklighetsförankrad, och en oro och rädsla som bygger på okunskap, fördomar eller tvivelaktiga ideologier", J.A.Diaz artikel i Svenska dagbladet 20/6/93.
} 


\section{Referenser}

Anders Lange och Charles Westin (1991) Ungdo men om invandringen, Rapport $\mathrm{nr} 9$ från Centrum för invandringsforskning (CEIFO), Stockholm universitet.

Anders Lange och Charles Westin (1984) Majoritet om minoritet. En studie $i$ etnisk tolerans $i$ 80-talets Sverige. En rapport från Diskrimineringsutredningen. Stockholm: LiberFörlag.

Banakar, Reza (1993) „Det offentliga samtalet om etnokulturella frågor", Häften för kritiska stu dier, nr 1-2, s 81-96.

Balibar, Etienne (1991) "Is There a Neo-Rasism'?" in Race, Nation and Class. Ambiguous Identities, E. Balibar och I. Wallerstein (eds.), London/New York: Verso.

Bauman, Zygmunt (1990) "Modernity and Ambivalence«, ingår i Global culture, Nationalism, globalization and modernity (red.) Mike Featherstone. A Theory, Culture \& Society special issue. London: Sage.

Brubaker, William R. (1990) "Immigration, Citizenship and the Nation-state in France and Germany: A Comparative Historical Analysis", International Sociology, vol 5, $\mathrm{nr} 4$, s. 379-407.

Diaz, Jose Alberto (1992) "Rasism utan ras?", Invandrare och Minoriteter, $\mathrm{nr} 3$.

Diaz, Jose Alberto (1993) Choosing integration. A theoretical and empirical study of the immigrant integration in Sweden, doktorsavhandling, Sociologiska institutionen, Uppsala universitet.

Diaz, Jose Alberto (1993b) »Integration, vad är det?", Tiden, nr 7 .

Gellner, Ernest (1983) Nation and Nationalism. Oxford: Basil Blackwell.

Hernes, Gudmund \& Knud Knudsen (1989) "Over grensen. om holdninger til innvandrere og asylsøkare", Tidsskrift for samfunnsforskning, vol 30, s. 27-60.

Hobsbawm, Eric (1992) "Whose fault-line is it anyway?" i New Statesman \& Society, 24 April.

Jaschke, Hans-Gred (1992) "Nationalismus und Ethnopluralismus. Zum Wiederaufleben von Ideen der 'Konservativen Revolution", ingår i
Aspekte der Fremdenfeindlichkeit. Beiträge zur aktuellen Diskussion, Institut für Sozialforschung (red.). Frankfurt/New York: Campus Verlag.

Jenssen, Anders Todal och Elin Pedersen (1991) "Jo mere vi er sammen, dess gladare blir vin? Kontakt, vennskap og konflikt mellon nordmenn og innvandrere, Tidsskrift for samfunnsforskning, vol 32, s. 23-52.

Lindberg, Christer (1991) "Etnocentrism och rasism", Invandrare \& Minoriteter, $\mathrm{nr} 1$.

Lodenius, Anna-Lena och Stieg Larsson (1991) Extremhögern. Stockholm: Tiden.

Lööw, Heléne (1993) Rasistisk och främlingsfientlig brottslighet. Myter och verklighet, papper framlagt vid 9. Nordiske Migrationsforskerseminar, Esbjerg, Danmark.

Kivisto, Peter and Dag Blanck (1990) (red.) American Immigrants and Their Generations. Studies and Commentaries on the Hansen Thesis after Fifty Years. Urbana: University Illinois Press.

Schwarz, David (1992) "En nödvändig normalisering" ingår i Bättre blandat än särbehandlat. Om kommunernas framtida invandrarpolitik. Svenska kommunförbundet.

SOU 1989:13, Mångfald mot enfald. Slutrapport från Kommissionen mot rasism och främlingsfientlighet. Del 1.

Taguieff, Pierre-André (1985) "Le neo-racisme differentialiste. Sur l'ambiguity d'une evidence commune et ses effects pervers: l'eloge de la difference", Langage \& Societé, vol. 34, s 69-97.

Vanneman, Reeve D. \& Thomas F. Pettigrew (1972) "Race and Relative Deprivation in the Urban United States", Race, vol. 13, s. 461486.

Westin, Charles (1987) Den toleranta opinionen. Inställning till invandrare 1987. Rapport $\mathrm{nr} 8$ från Delegationen för invandrarforskning (DEIFO). Stockholm.

Diaz - Främlingar, fiender och medborgare 


\section{Summary \\ Strangers, enemies and citizens. \\ A contribution to the analysis of \\ xenophobia in Sweden.}

The discussion about xenophobia is prone to definitional and analytical obscurity. This article analyzes the role of major social factors in the construction of xenophobia as relevant political phenomenon. The purpose is to present a characterization of xenophobia based on two kinds of antagonisms between the native and immigrant population. The first type of concrete antagonisms focuses on how native individuals perceive immigration and immigrants in specific social and practical situations. These antagonisms are mainly related to competition on scarce resources. The second type of antagonisms deals with a collective dimension through which concrete tensions and relations of competition are connected to feelings of identity and solidarity with a greater human community among native people, namely the nation. As a politically relevant phenomenon, xenophobia depends on the ideological construction of a national "wer which makes possible the collective definition of strangers as an antagonistic "them", to which all people, who are not regarded as belonging to the Swedish national community, are included. It is also argued, that citizenship may be an important policy mechanism to increase the immigrants' belonging to a national community, which is not be built upon exclusive ethnical and cultural principles. 